\title{
FUNDING AGENCIES IN INDIA FOR RESEARCH IN PHARMACY
}

Seema Mahor*1, Hina Chadha' Smriti Ojha'

1Department of Pharmaceutical Sciences, Vishveshwarya Group of Institutions, G B Nagar Dadri, Greater Noida, 203207, U.P. India

\section{ABSTRACT}

A Funding Agency is any external organization, public or private, which undertakes a contractual agreement with the University to sponsor research or an entrepreneurial activity. The funding agency often dictates how their funds may be used, what deliverables are expected, and what reports are required. Funding agencies bear the entire cost of research at Carleton and provide overhead funding to cover the indirect costs of research. In India various funding agencies are available which provide grants for a research in a various field. These agencies conduct research schemes to promote the research in India in science or other medical stream and provide a grant for research in various areas.

Keywords: Funding agency, Fellowship, Science, Research, Research grant 


\section{Introduction}

Funding is the process of providing resources to finance a need for any program or project, and this is usually done in the form of money, it can also take the form of effort or time from an organization or company. Generally, the word funding is used when a firm uses its internal reserves to satisfy its necessity for cash, while the term financing is used when the firm acquires capital from any external sources [1]. Research funding is a common term generally covering any funding for scientific research, in the areas of "hard" science and technology and social science. It is a competitive a process in which potential research projects are evaluated and only the most promising receive funding for research or any special projects. The processes, which are run by government, corporations or foundations, allocate scarce funds in fields of social science and science technology [2]. Research funding can split into two parts such as commercial and non-commercial part. Research and development departments of a corporation normally provide commercial research funding. Whereas, non-commercial research funding is obtained from charities, research councils,

or government agencies. Organisations that require such funding normally have to go through competitive selections. Only those that have the most potential would be chosen. Funding is vital in ensuring the sustainability of certain projects [3].

\section{Different funding agencies are}

1. Department of Science and
Technology (DST)

2. Department of Biotechnology (DBT)
3. All India Council for Technical Education (AICTE)

4. University Grants Commission (UGC)

5. Council of Scientific and Industrial Research (CSIR)

6. Indian Council of Medical Research (ICMR)

7. Department of Ayurveda, Yoga and Naturopathy, Unani, Siddha and Homeopathy (AYUSH)

8. Defence Research and Development Organisation (DRDO)

\section{1) Department of Science and Technology (DST)}

The Department of Science and Technology plays a vital role in promotion of Science and Technology department in the country. Science and Technology Policy 2003 states that "Special emphasis will be placed on equity in development, so that the benefits of technological growth reach the majority of the population, particularly the disadvantaged sections, leading to an improved quality of life for every citizen of the country." The Department has wide ranging activities ranging from promoting high end basic research and development of cutting edge technologies on one hand to service the technological requirements of the common man through development of appropriate skills and technologies on the other. The setting up of a separate Department of Biotechnology (DBT), under the Ministry of Science and Technology in 1986 gave a new impact to the development of the field of novel biology and biotechnology in India. In more than a decade of its existence, the department has promoted and accelerated the pace of development of biotechnology in the country. Through 
several research projects, demonstrations and creation of infrastructural facilities a clear visible impact of this field has been observed. The department has made significant achievements in the growth and application of biotechnology in the broad areas of health care, agriculture, animal sciences, environment, and industry [4].

\section{Soft Loan for Pharmacy Industrial R\&D Projects}

It provide loan for various pharma companies and proposal may be submitted by any Indian company or firm engaged in drug development manufacturing jointly with

- National laboratory under CSIR, ICMR, etc.

- University II department/other academic institution such as IIT etc.

- Any other publicly funded R\&D Institution

\section{Name of scheme}

- Pharmaceuticals Research and Development Support Fund (PRDSF) Programme

- Deep Continental Studies (DCS)

- Himalayan Glaciology (HG)

- Indian Climate Research Programme (ICRP)

- Instrument Development Programme (IDP)

- International S\&T Cooperation (ISTC)

- Joint Technology Projects under STAC/IS-STAC

- Monsoon and Tropical Climate (MONTCLIM) and Agro meteorology

- Natural Resources Data Management System (NRDMS) [4]
Components of grant and contact address

Salaries and wages

Consumables materials

Domestic Travel

Patent Filing

Equipment

Software

\section{Contact Address}

The Adviser and Head (TDT)

Department of Science and Technology, Technology Bhawan, New Mehrauli Road,

New Delhi 110016

Telefax: 011 1-26510686

E-mail: laxman@nic.in

Website: www.dst.gov.in [5]

\section{2) Department of Biotechnology (DBT)}

The setting up of a separate Department of Biotechnology (DBT), under the Ministry of Science and Technology in 1986 provided a new impression to the development of the field of modern biology and biotechnology in India. In more than a decade of its existence, the department has promoted and accelerated the pace of development of biotechnology in the country. Through several research projects, demonstrations and creation of infrastructural facilities a clear visible impact of this field has been also observed. The department has made significant achievements in the growth and application of biotechnology in the broad areas of agriculture, animal science, health care, environment, and industry [6]. Main objective of DBT is to promote the goals of the Institute and to facilitate re-entry of scientists of Indian origin working abroad [7]. 


\section{Name of scheme}

- Agriculture

- Bioinformatics

- Biotech productand process development

- Basic research

- Human resource development

- Infrastructure facilitiesMedica biotechnology

\section{Eligibility of fellowship}

Applicants for this Fellowship should possess Ph.D., M.D., or an equivalent degree relevant to biomedical genomics, with an outstanding track record reflected in publications and other professional achievements. Applicants must not have affiliation to an institution in India Academic Institutions, research and development Laboratories, Autonomous bodies; Industries "ll etc can submit a proposal in the prescribed format any time during the year [7].

\section{Application Procedure}

Each applicant should provide Curriculum vitae and the following documents

-Summary of pre-doctoral training with details of major courses taken and grades obtained (about 10 sentences)

-Highlights of doctoral training and publications (about 20 sentences)

-Highlights of post-doctoral training and publications (about 30 sentences)

-Problems to be addressed in the next 5 years with clear indication of the importance of the problems and methodologies to be adopted in solving those (about 3 pages)

- Description of long-term (5-15 years) professional goals (about 1 page)

-A specific project proposal (with clear descriptions of objectives methodologies, importance and timelines) to be carried out in the next 5 years, with budget and justification (10 pages) [7].

\section{Areas of research support}

Animal Biotechnology

Aquaculture and Marine biotechnology

Basic Research in Biotechnology

Bio fuels

Bioinformatics

Biological Control of Plants pests, diseases and weeds

Bio prospecting and Molecular Taxonomy Biotech process engineering and industrial biotechnology

Biotechnology of Medicinal and Aromatics plants

Biotechnology of Silkworms and hostplants

Crop Biotechnology

Environment and Conservation

Biotechnology

Food Biotechnology

Medical Biotechnology (Vaccines,

Diagnostics, Drug Development, Human Genetics and Genome Analysis, Seri Biotechnology, Stem Cell Biotechnology) Microbial Biotechnology

Plant tissue Culture

Nano Biotechnology

Women Biotechnology and Programme for Rural Areas and SC/ST population Patent Facilitation [8].

\section{Contact Address}

Scientist In-charge, Project Registry Cell, Department of Biotechnology,

Block 2, 7th Floor, C.G.O. Complex, Lodi Road, New Delhi - 110003

Website: www.dbtindia.gov.in, www.btisnet.gov.in

\section{3) All India Council for Technical Education (AICTE)}


The All India Council for Technical Education (AICTE) was established by an Act of Parliament in the year 1987, with a view to promote proper planning and coordinated Development of technical education system throughout the country. The Council has been performing its regulatory, planning and promotional functions through its Bureaus, like Administration, Finance, Planning and Coordination, Under Graduate Studies, Post Graduate Education and Research, Faculty Development Programme, Quality Assurance, and Research and Institutional Development Bureaus, and through its Regional Offices located in various parts of the country The Council invites fresh proposals annually from AICTE approved technical institutions, University Departments, Government Institutions, Grant-in-aid Institutions and Accredited Institutions in the private sector for financial assistance for schemes operated by the RID Bureau. For five year old institutions in $\mathrm{J}$ and $\mathrm{K}$ State and NorthEastern states, accreditation criterion is not mandatory [9].

\section{Proposal can be submitted by}

- Centrally funded Institutions may apply, however.

- Centrally funded Institutes such as IITS, IISC, IIM's, NIT's are not eligible for these schemes as they are directly funded by Ministry of Human Resource Development, New Delhi.

- Professional, Bodies/Societies, Indus trial Units or Houses, NGO's Institutio ns/Departments not approved by AICTE and Non-accredited departments of Self-financing Institutions are NOT ELIGIBLE to apply for RID Bureau Schemes [10].

\section{Name of scheme}

i) Research development schemes

Institutional

a) Modernization and removal of obsolescence scheme (MODROBS)

- Main objectives are to equip technical institutions with modern infra-structural facilities in laboratories, workshops, computing facilities to enhance functional efficiency for teaching, training and research purposes. Creation of new laboratories is not envisaged. Maximum funding is Rs. 15 lakh with 2 years duration.

- The aims are contemporary Lab Work, relevant project work, indirect benefits to faculty and students of the institution through training programmes and consultancy work [11].

b) Research Promotion Schemes (RPS) Aim of RPS is to create research ambience by promoting research in technical discipline and innovations in established and emerging technologies, and to generate master's and doctoral degree candidates. The three research avenues within RPS are the following [11].

- Proof of concept work It includes independent research activity which can lead to growth of knowledge in an area, which can grow into a major project. Funding for such projects would be limited to a one time grant of Rs.5-10 lakhs.

- Capacity building for research- In this a young faculty (30 years limit) which grant of Rs 10-12 lakhs is encouraged to carry out research at Doctoral level in a reputed 
institution. The funding can be used for both drawing of salary during leave without pay condition and towards purchase of equipments to carry out research in a novel area.

- Patentable technology development by a group of faculty members, having proven track record, who aim at developing new research facilities, at the parent institution, being motivated chiefly by high-end output such as patentable technologies. Funding to such projects would be limited to one time grants of Rs. 20 lakhs [11].

ii) Industry-Institute

Interaction

Schemes these are of following types

a) Industry Institute Partnership Cell (IIPC)

Main objective of this scheme is to establish institute-industry liaison by encouraging:

- Conduct of industrial training programmes

- Facilitating exchange of resource personnel

-Carry out industrial R\&D

-Conduct of industrial visits

-Developing appropriate curricula

and

-Undertake consultancy services, etc.

\section{b) Entrepreneurship Development}

\section{Cells (EDC)}

Objective of this is to encourage students to consider selfemployment as a career option and provide training in entrepreneurship. c) National Facilities in Engineering and Technology with Industrial Collaboration

(NAFETIC)

Objective of this is to establish national level facilities in the frontier areas of Engineering and Technology through collaboration between industry(s) and institutions for product development, basic research, trouble shooting, and consultancy, testing and training purposes.

d) Nationally Coordinated Project (NCP)

Objective of this is to plan, coordinate and execute integrated R\&D programmes at national level by a group of institutions. The technical/ financial/ administrative deliverables are to be spelled out clearly by the networking institutions with the lead institution being an IIT/ISC/IIM/NIT [1 1].

\section{Areas of research support}

Pharmacy, Engineering and Technology, Architecture, Town Planning, Management, Hotel Management and Catering Technology, Applied Arts and Crafts.

\section{Contact Address}

All India Council for Technical Education,

NBCC Building, East Wing, $4^{\text {th }}$ Floor

Pragati Vihar, Bhisham Pitamah Marg

New Delhi -110003

Telefax No: (011) 24369632

E-mail: rid@aicte.ernet.in Website: www.aicte.ernet.in 


\section{4) University Grant Commission} (UGC)

The objective of the scheme is to provide an additional special development grant to young colleges who have been included by the UGC under Section 12(B) of UGC Act, 1956 in IX Plan and this scheme aims to ensure the equity and access of higher education to deserving colleges.The assistance available under the scheme will be in addition to General Plan Development Fund for X Plan. The colleges may seek a grant for strengthening basic infrastructure viz. books and journals including a book bank, basic teaching equipment, scientific equipment, sports kit. To provide assistance for extension/renovation of existing building and construction of new buildings including the development of sports facilities [12].

\section{5) Council of Scientific and Industrial Research (CSIR)}

The major functions of CSIR include promotion, guidance and coordination of scientific and industrial research in India, establishment or development of and assistance to existing special institutions or departments for scientific study of problems affecting particular industries and trades, award of fellowship, utilization of Council's R\&D results for industrial development, collection and dissemination of S\&T information; and technology generation, absorption and transfer. Main objective is to promote research work in the field of science and technology including agriculture, engineering and medicine. Multidisciplinary projects which involve interorganisational cooperation (including that of CSIR Laboratories) are also considered. Preference is given to schemes which have relevance to research programmes of CSIR laboratories Professors/Scientists and other experts in regular employment in Universities, IITs, Post Graduate Institutions, Colleges, recognized R\&D laboratories etc can submit a proposal in prescribed format any time during the year [13].

\section{Areas of research support}

Science and Technology including agriculture, engineering and medicine.

\section{Components of grant}

Fellowships,

contingencies

and

equipment

\section{Name of scheme}

\section{- Research Schemes}

The main objective of this scheme is to promote research work in the field of S\&T including agriculture, engineering and medicine. Multi-disciplinary projects which involve inter-organisational cooperation (including that of CSIR Laboratories) are also considered. Preference is given to schemes which have relevance to research programmes of CSIR laboratories. Professors/Scientists and other experts in regular employment in Universities, IITs, Post Graduate Institutions, Colleges, recognized R\&D laboratories etc can submit a proposal any time during a year in a prescribed format [14].

\section{Areas of research support}

Science and technology including agriculture, engineering and medicine.

\section{Components of grant}

Fellowships

Contingencies

Equipment 


\section{Items not allowed out of grant}

International travel, furniture/office equipment

\section{- Sponsored Schemes}

The Directors of CSIR laboratories may invite applications for research grants in specific areas of interest to their respective laboratories. Professors, Scientists and other experts in regular employment in Universities, IITs, Post Graduate Institutions, Colleges, recognized R\&D laboratories etc can submit a proposal any time during a year in a prescribed format [14].

\section{Areas of research support}

Science and Technology including agriculture, engineering and medicine.

\section{Components of grant}

Fellowships

Contingencies

Equipment

\section{Items not allowed out of grant}

International travel, furniture/office equipment

\section{- Emeritus Scientist Scheme}

The main objective of scheme is to provide support to superannuated outstanding scientists to pursue research in their respective field of specialization and having relevance to the programmes of CSIR. A scientist who has been actively engaged in scientific research during the preceding five years of superannuation can submit a proposal any time during a year in a prescribed format [14].

\section{Areas of research support}

Science and Technology including agriculture, engineering and medicine.

\section{Components of grant}

Scientist allowance
Fellowship

Contingency

Items not allowed out of grant

Furniture/Office equipment

- Research

Fellowships/

\section{Associateships}

Shyama Prasad Mukherjee Fellowship

Senior Research Associate ship

Recognition of Excellence

Shanti Swarup Bhatnagar Prize

CSIR Young Scientist Award

\section{Other Science and Technology Promotion} Programmes

CSIR Programme on Youth Leadership in Science

CSIR Diamond Jubilee Research Interns Award Scheme

Partial Financial Assistance for holding National/International Conferences/ symposium/

Seminar/ Workshops in India

Partial Travel Grants to Research Scholars

Entrepreneurship Support to Research Scholars

Faculty Training Programme and Adoption of Schools and Colleges by CSIR Laboratories

\section{Contact Address}

The Head,

Human Resource Development Group

Council of Scientific and Industrial Research,

CSIR Complex, Library Avenue, Pusa New Delhi - 110 012, Tel- (011) 25748632, 25721585

Fax.No: (011) 25840887, 25860595,

E-mail: csircx@nda.vsnl.net.in, Website: http://csirhrdg.res.in

\section{6) Indian Council of Medical Research ICMR}


The primary aim of the ICMR is to promote research in the various areas of country like in the fields of medicine, public health and allied areas. The Council promotes biomedical research in the country through intramural research (through Institutes totally funded by ICMR) and extramural research (through grants -inaid given to projects in non-ICMR Institutes) [15].

\section{Name of the scheme}

- Ad-hoc Research Schemes

- Senior Research Fellowship/Research Associate

- Emeritus Medical Scientist Scheme

\section{Ad-hoc Research Schemes}

It is Open-ended Research on the basis of applications for grants-in-aid received from scientists in non-ICMR Research Institutes located in different parts of the country The Indian Council of Medical Research provides financial assistance to promote biomedical and health research. The assistance is provided by way of grants to scientists in regular employment in the Universities, medical colleges, postgraduate institutions, recognized research and development laboratories and NGOs. Proposals are received throughout the year on the prescribed format, which can be obtained on request from the DirectorGeneral, ICMR. Forms can also be downloaded from ICMR website [16].

\section{Areas of research support}

-Communicable diseases including viral diseases, cholera, leprosy, malaria etc.

-Reproductive health including fertility control.

-Maternal and Child Health care system. -Nutritional and major metabolic disorders.
-Primary health care, alternative health care systems.

-Non-communicable diseases including cancer, mental health, cardiovascular, oral health, etc.

-Occupational and other environment related health problems i.e. asthma.

-Drug research including medicinal plants and indigenous or traditional systems of medicine.

-Basic medical research in disciplines such as anatomy, allergy, anthropology,

Physiology, biochemistry, immunology, cell and molecular biology, genetics,

Pharmacology.

\section{Components of grant}

Research staff, Equipment,

Contingencies, Travel, Overheads

Financial ceiling (Financial

Ceiling is up to Rs.30 Lakhs for the total duration of the project)

\section{Items not allowed}

Basic infrastructure, building, foreign travel etc.

\section{Senior Research Fellowship/Research Associate}

Senior Research fellowships provide opportunities to bright young men and women to pursue research and training invariably leading to PhD/MD etc. Research Associateships are awarded to encourage young research workers who already have good quality published work to their credit to pursue research work in biomedicine on specific research programmes as post doctoral fellows. Any young scientist who fulfils the prescribed criteria of age and educational qualifications can submit applications to ICMR to carry out research in the field of biomedical sciences at the permanent institutes of the council, other biomedical 
research institutes, medical colleges and universities in India where adequate laboratory and other facilities to carry out biomedical research are available [17].

\section{Emeritus Medical Scientist Scheme}

This scheme is for retired medical scientists and teachers, the Council offers the position of Emeritus Scientist to enable them to continue or take up research on specific biomedical topics.

\section{Contact Address}

Director General, Council of Medical Research,

V. Ramalinga swami Bhawan, Post Box No. 4911

Ansari Nagar, New Delhi- 110029

Telephone: 91-11-26588895,

91-1126588980, 91-11-26589794,

91-11-26589336, 91-11-26588707

Fax: 91-11-26588662

\section{7) Department of Ayurveda, Yoga and Naturopathy, Unani, Siddha and Homoepathy (AYUSH)}

The AYUSH Systems include Ayurveda, Yoga and Naturopathy, Unani, Siddha, Homoeopathy and include therapies documented and used in these Systems for the prevention and cure of various disorders and diseases. The Department of AYUSH has introduced a Scheme for extra-mural research in addition to the intra-mural research undertaken by four Research Councils for Ayurveda and Siddha, Unani, Homoeopathy, Yoga and Naturopathy set up by the Ministry of Health and Family Welfare three decades ago. The off take and output from this scheme has so far been limited and has not been able to meet the standards for scientific enquiry and outcome effectively. The Department has taken up a series of programs/interventions wherein evidence based support for the efficacy claims is needed. Safety, quality control and consistency of products are also very much required [18].

\section{Name of scheme}

- Extra-mural Research (EMR) project Scheme of AYUSH Systems of medicine Accreditation of Organizations for Research and Development in the fields of AYUSH.

- Golden Triangle Partnership (GTP) Scheme for validation of traditional Ayurvedic Drugs and development of new drugs [19].

\section{Extra-mural Research (EMR) project Scheme}

The main purpose of these schemes are to develop evidence based support on the efficacy of AYUSH drugs and therapies and generate data on safety, standardization and quality control of AYUSH products and practices it also investigate the fundamental principles of Indian Systems of Medicine and generate a data base on various aspects of AYUSH practices. It also generates data on Heavy metals, microbial load, Pesticide residues, Safety and Toxicity in the raw drugs and finished products like ASU and $\mathrm{H}$ drugs. It also used appropriate technologies for development of single and herbal products to make it globally acceptable. It also develop the products those have IPR potentials to attract national and multinational pharmaceutical companies [20].

The institutions or investigators who are seeking a project from the Department of AYUSH should have adequate infrastructure to pursue the research project and knowledge. In case of clinical research, the hospital, and 
laboratory facilities for bio-chemical, pathological, radiological and electrophysiological investigations supported with necessary equipment relevant to the project should be available [21].

\section{Golden Triangle Partnership (GTP)} Scheme

Main objectives of these schemes are as follows

- To bring safe, effective and standardized Ayurvedic products for the identified disease conditions.

- To develop new Ayurvedic and plant based products effective in the disease conditions of national and global importance.

- To have best quality, safe and effective products.

- To utilize appropriate technologies for development of single and poly-herbal products to make it globally acceptable.

- The product should have IPR potential to attract national and multinational pharmaceutical companies [21].

\section{Contact Address}

Director (Ayurveda and Siddha; Unani, Homoeo; Yoga and Naturopathy),

Department of AYUSH, 61-65, Institutional Area,

Janakpuri, New Delhi -1 10058

Tel. No.: (01 1) 28520430

(011) 28525520 (Ayurveda. and Siddha),

(011) 28521981 (Unani),

(011) 28525523 (Homoeo)

Fax.No: (011) 28520435 (Yoga and Naturopathy),

(011) 28520748 (Ayurveda. and Siddha)

\section{8) Defence Research and Development Organisation DRDO}

DRDO is directly related in the formulation and execution of programmes of scientific research, design and development, testing and evaluation leading to induction of state-of-art weapons and various equipment which would compete and compare favourably with its contemporary systems available elsewhere in the world. It consists of a chain of laboratories/establishments situated all over the country, pursuing assigned scientific goals with delegated powers under the policy direction provided by the headquarters in New Delhi. DRDO also supports a substantial amount of extramural research in academic institutions and other laboratories on defence related problems through various grants -in-aid schemes and other sponsored projects [22].

\section{Name of scheme}

\section{Extramural Research Scheme}

In this type of scheme research sponsored in academic institutions under the extramural research scheme focuses on research on phenomena or observations that are not understood, and that lack of understanding is identified as an obstacle to scientific or technological progress in the broad topic area of relevance to military research and development. The knowledge base so generated is embodied in high-quality technical manpower and in the new understanding, techniques and designtools developed through the basic research funded. This new knowledge can also provide pathways to significant 
advances in the mission-effectiveness of traditional military roles [22].

Collaterally with the expanded knowledge-base created, a primary endresult of the research that is funded under the extramural research program is a networked group of qualified people whose expertise resulting from the research can be drawn-upon to build an exploitable area of new technology that has potential military applicability. The extramural research scheme also supports the instrumentality of Memoranda of Collaboration between DRDO Laboratories \& Establishments and academia. These Memoranda of Collaboration invariably involve more than on DRDO establishment and cover explorations and investigations on a range of topics within a broad subject arena that generically cross-link the research activities of the collaborating Laboratories and Establishments and the research-disciplines of the selected collaborating academic institution. Such institutional cross-linking is organic, not episodic, and is made operational in a MoC through a management structure which includes in its standing arrangements representation of directors of the collaborating DRDO institutions [22].

\section{Contact Address}

The Director,Directorate of Extramural and Intellectual Property Rights Defence Research and Development Organisation, West Block 8, Wing 5, 1st Floor, R.K. Puram New Delhi - 11006 , Telefax 011-26170928

E-Mail: erip_er@drdohq.res.in, Website: www.drdo.com
[1]. Kaschny (2018,) Martin, Innovation and Transformation. Springer Verlag. ISBN 978-3-319-78524-01.

[2]. Funding of Science, retrieved on Jan 24, 2013 from, http:// en.wikipedia.org/wiki/ Funding of science.

[3]. Imperial College London (2014), Types of research funding, http://www.imperial. ac.uk/researchsupport/funderinformation /typesofresearchfunding (Accessed:15 October 2014).

[4]. General Information on Research and Development Funding Schemes of Central Government Departments/Agencies, Department of Science \& Technology, retrieved on Jan 31, 2013 from, http://dst.gov.in, r\&d_funding/rdfs $1 . h t m$

[5]. Drugs \& Pharmaceutical Research, Department of Science \& Technology, retrieved on Jan 31, 2013 from, http://www.dst.gov.in/scientificprogram me/ td-drugs.htm.

[6]. Indian Council of Medical Research; Funding Agencies; chapter 3; page no,23, retrieved on Jan 22, 2013.

[7]. Fellowships at the national institute of biomedical genomics, retrieved on Jan 31 , 2013 from,

http://dbtindia.nic.in/index.asp

[8]. General Information on Research \& Development Funding Schemes of Central Government Departments/Agencies, Department of Science \& Technology, retrieved on Jan

\section{References:}


31. 2013 from,

http://dst.gov.in/r\&d_funding/rdfs $1 . h t m$

[9] All India Council for Technical Education; approval process handbook; pdf, 2013 - 2014; retrieved on Jan 22, 2013 from, http://www.informindia.co.in/ education/Approval

Process_ Handbook_091012.

[10].All India Council for Technical Education; scheme details, 2010-11; page no. 2-7, retrieved on Jan 22, 2013 from, http://www.aicteindia.org/ downloads/ Guidelines_Scheme_Details_pdf

[11]. General Information on Research and Development Funding Schemes of Central Government Departments/Agencies, Department of Science \& technology, retrieved on Jan 24, 2013 from, http://J:/Review/rdfs 1.htm

[12]. University grant commission www.ugc.ac.in

[13]. Council for Scientific and Industrial Research, retrieved on Jan 24, 2013 from, http://en.wikipedia.org/ wiki/Council for Scientific and Industrial Research.

[14]. Gaondalia A V, Shah K A (2013), funding agencies in India for Research Science and Technology, Pharma science and monitor, An international journal and pharmaceutical sciences Volume 4, issue-3.

[15]. Indian Council of Medical Research, Funding Agencies; chapter 3, retrieved on Jan 22, 2013 from, http://icmr.nic.in/hmsc_document/fundin g_agencies

[16]. AD-HOC Research schemes, retrieved on Feb 2, 2013 from, http://icmr.nic.in/ad-hoc.htm

[17] Research fellowships/Associate ships, retrieved on Feb 2, 2013 from, http://icmr. nic.in/fellow.htm

[18]. Department of Ayurveda, Yoga and Naturopathy, Unani, Siddha and Homoeopathy, retrieved on Jan 29, 2013 from, http://en.wikipedia.org/ wiki/ Department of Ayurveda, Yoga and Naturopathy, Unani, Siddha and Homoeopathy.

[19]. Exploring Funding Opportunities, retri eved on Jan 29, 2013 from, http://www.sli deshare.net/sreedharra0313/microsoftpowerpointfundingopportunities.

[20]. Government of India ministry of health and family welfare department of Ayurveda, Yoga and Naturopathy, Unani, Sowa rigpa and Homeopathy scheme for extra and intra mural research (EMR) Vol 4, Issue - 3, Apr-Jul 2013

[21]. Exploring Funding Opportunities (201 3) retrieved from, http://www.slideshare.n et/sreedharrao313/microsoftpowerpointfundingopportunities.

[22]. John Pike (2010), defence research and development organisation, globalsecurity.org.23 April. 